\title{
PEMBERDAYAAN MASYARAKAT DALAM TATA KELOLA PARIWISATA DI KAMPUNG WISATA DEWO BRONTO YOGYAKARTA
}

\author{
${ }^{1}$ Rumsari Hadi Sumarto, ${ }^{2}$ Lukas Dwiantara \\ 1.ASMI DESANTA - Kandidat Doktor FIA Universitas Brawijaya, ${ }^{2}$ ASMI SANTA MARIA \\ rumsarimpa@gmail.com, lukasdwiantara@gmail.com \\ Yogyakarta 55182 - Indonesia
}

\begin{abstract}
This study aims to describe and analyze community empowerment activities in the Dewo Bronto Tourism Village in Yogyakarta through the concept of Community-Based Tourism. This study uses qualitative research that describes community empowerment through the concept of Community Based Tourism objectively based on data findings in the field. Data collection techniques using observation, interviews, and documentation. Community empowerment in the field of tourism in the tourism village is carried out through various fields such as culinary business, the production of natural dyes of batik, batik training, transportation, arts and cultural attractions. This effort can support the development of tourism in the Dewo Bronto Tourism Village. However, community empowerment needs to be supported by the ability of the community to create a brand for a tourist village so that the Tourism Village is better known by tourists. In the future it is necessary to do research on millennial communities who are familiar with the digital world so that they can promote the Village Tourism digitally. The impact of the tourist village is better known to tourists globally.
\end{abstract}

\section{Keywords: Community; Empowerment; Community Based Tourism; Tourism; Village}

\begin{abstract}
Abstrak
Penelitian ini bertujuan untuk mendeskripsikan dan menganalisis kegiatan pemberdayaan masyarakat di Desa Wisata Dewo Bronto di Yogyakarta melalui konsep Pariwisata Berbasis Masyarakat. Penelitian ini menggunakan penelitian kualitatif yang menggambarkan pemberdayaan masyarakat melalui konsep Community Based Tourism secara obyektif berdasarkan temuan data di lapangan. Teknik pengumpulan data menggunakan observasi, wawancara, dan dokumentasi. Pemberdayaan masyarakat di bidang pariwisata di desa wisata dilakukan melalui berbagai bidang seperti bisnis kuliner, produksi pewarna alami batik, pelatihan batik, transportasi, seni dan atraksi budaya. Upaya ini dapat mendukung pengembangan pariwisata di Desa Wisata Dewo Bronto. Namun, pemberdayaan masyarakat perlu didukung oleh kemampuan masyarakat untuk membuat merek untuk desa wisata sehingga Desa Wisata ini lebih dikenal oleh wisatawan. Di masa depan perlu dilakukan penelitian pada komunitas milenial yang akrab dengan dunia digital sehingga mereka dapat mempromosikan Desa Wisata secara digital. Dampak desa wisata lebih dikenal wisatawan secara global.
\end{abstract}

Kata Kunci: Desa; Masyarakat; Pemberdayaan; Pariwisata; Pariwisata Berbasis Masyarakat;

Open Access at: http://ojs.uho.ac.id/index.php/PUBLICUHO/index

Journal Publicuho is licensed under a Creative Commons Attribution 4.0 International License. 


\section{PENDAHULUAN}

Pariwisata di era modern ini mengalami kecenderungan positif untuk berkembang mengingat masyarakat saat ini sering berwisata ke destinasi-destinasi wisata yang ada di berbagai negara atau pun berbagai daerah di Indonesia. Kota Yogyakarta sebagai salah satu daerah yang terkenal dengan seni dan budaya banyak mengusung wisata seni dan budaya sebagai ikon wisata di Kota Yogyakarta. Namun demikian, berbagai atraksi seni dan budaya yang ditampilkan dan destinasi wisata yang ada di Kota Yogyakarta belum semua mampu menarik para wisatawan. Wisatawan yang datang ke Kota Yogyakarta cenderung berpusat di sekitar Malioboro, Titik Nol, Alun-alun Utara dan Alun-alun Selatan, Taman Pintar, kemudian bergerak ke Taman Sari dan Kebun Binatang Gembiraloka. Sementara itu destinasi wisata lain yang ada di Kota Yogyakarta belum mendapat perhatian sepenuhnya dari para wisatawan. Hal ini berimbas terhadap lama tinggal wisatawan di Kota Yogyakarta yang belum memenuhi target. Target di tahun 2018 adalah 2,02 tetapi realitanya 2,01 hari (Laporan Kinerja Dinas Pariwisata Kota Yogyakarta 2018). Adapun beberapa faktor yang mempengaruhi lama tinggal wisatawan diantaranya adalah daya tarik wisata yang kurang variatif, minimnya daya tarik wisata baru yang muncul, atraksi wisata malam masih terbatas dan masih terpusat di Kawasan Malioboro, alun alun Utara dan Selatan (Laporan Kinerja Dinas Pariwisata Kota Yogyakarta 2018).

Kampung Wisata sebagai salah satu destinasi di Kota Yogyakarta juga belum banyak dikenal oleh para wisatawan. Kampung-kampung wisata yang ada di Kota Yogyakarta sebenarnya dapat menjadi tujuan wisata bagi para wisatawan yang berkunjung ke Yogyakarta. Kampung Wisata Dewo Bronto sebagai salah satu kampung wisata di Kota Yogyakarta juga belum mendapat perhatian khusus dari para wisatawan walaupun kampung wisata tersebut memiliki beragam atraksi seni dan budaya serta beberapa produk menarik yang dapat menjadi alternatif wisata bagi para wisatawan.

Salah satu atraksi budaya yang digelar di Kampung Wisata Dewo Bronto diantaranya dirilis oleh Bali Post.

Satu upacara adat yang sudah rutin digelar setiap tahun adalah Upacara Adat Merti Tumpeng Robyong. Lokasinya di bantaran Kali Code. Anda bisa menikmati makan bersama dengan warga masyarakat. Karena, acara ini memang diisi dengan makan bersama atau dahar kembul. "Ini semua sebagai wujud rasa syukur atas rahmat serta karunia Tuhan Yang Mahaesa selama ini," jelas Marsudi, Ketua Kampung Wisata Dewa Bronto, Jumat (14/4). http://www.balipost.com/news/2017/04/15/5547/Ajak-WisatawanMakan-Bersama (diakses 1 November 2019).

Kampung Wisata Dewo Bronto dapat menjadi salah satu alternatif tujuan wisata di Kota Yogyakarta bila masyarakat di kampung tersebut diberdayakan sehingga mampu menarik minat wisatawan berkunjung ke kampung tersebut mengingat kampung ini memiliki 
beragam atraksi seni dan budaya, wisata kuliner dan industri batik. Pemberdayaan masyarakat khususnya masyarakat kampung wisata perlu dikembangkan untuk mendukung pengembangan pariwisata di kampung-kampung wisata khususnya Kampung Wisata Dewo Bronto sehingga menjadi lebih variatif. Masyarakat di Kampung Wisata Dewo Bronto sangat memahami kegiatan apa saja yang dapat diberdayakan sehingga kegiatan seni dan budaya menjadi atraksi yang dapat digelar kepada para wisatawan dan wisata kuliner atau industri wisata apa saja yang dapat dinikmati para wisatawan. Pemerintah Kota Yogyakarta seyogyanya juga perlu mendukung penuh pengembangan wisata di kampung-kampung wisata Kota Yogyakarta termasuk Kampung Wisata Dewo Bronto.

Studi tentang pariwisata yang berhubungan dengan pengembangan pariwisata diantaranya dikemukakan oleh Pitana 2009, Utama 2012, Sunaryo 2013, Damanik 2013, Sedarmayanti 2014. Pariwisata merupakan kegiatan dari orang-orang yang pergi dan tinggal di suatu tempat untuk berlibur dan tujuan lain dan di dalam kegiatan tersebut terjadi interaksi antara wisatawan dengan sektor swasta, pemerintah, komunitas dan pihak-pihak lain yang mengelola wisatawan (Richardson dan Flicker dalam Pitana dan I Ketut Surya Diarta 2009, Pitana dan I Ketut Surya Diarta 2009). Pariwisata berdampak pada kehidupan perekonomian di suatu negara di mana Pariwisata sebagai katalisator dalam pembangunan (Yoeti 2008: 25). Pengembangan pariwisata di suatu negara atau suatu daerah berdampak positif terhadap negara atau daerah tersebut dalam kehidupan perekonomian bahkan terhadap masyarakat di daerah wisata dapat meningkatkan taraf hidup masyarakat tersebut. Oleh karena itu, pariwisata menjadi semakin berkembang karena memberi dampak signifikan bagi kemajuan suatu negara.

Kebijakan pembangunan di bidang pariwisata yang mengkaitkan dengan pemberdayaan masyarakat di destinasi wisata (Community Based Tourism/CBT) dikemukakan oleh Sunaryo (2013). Sedang teori yang mengulas pemberdayaan masyarakat secara umum diantaranya dikemukakan oleh Sunyoto (2008), Soetomo (2013), Mardikanto (2017). Soetomo menegaskan bahwa melalui proses pemberdayaan, negara harus memberikan sebagian kewenangannya atau sebagian powernya kepada masyarakat (2013: 88). Pemerintah daerah juga seyogyanya memberikan sebagian kekuasaannya kepada masyarakat untuk bersama-sama membangun daerahnya. Ditambahkan oleh Adimiharja bahwa pemberdayaan masyarakat telah dimengerti sebagai suatu proses yang tidak saja hanya mengembangkan potensi ekonomi masyarakat yang sedang tidak berdaya, namun demikian juga harus berupaya meningkatkan harkat dan martabat, rasa percaya diri dan harga dirinya serta terpeliharanya tatanan nilai budaya setempat (Sunaryo 2013: 215). Dengan demikian, pemberdayaan penting dilakukan dalam rangka mendapatkan manfaat keuntungan dan dapat meningkatkan rasa percaya diri dan harga diri dari masyarakat yang diberdayakan. Pemberdayaan masyarakat menjadikan masyarakat yang sebelumnya tidak 
memiliki kekuatan dan menjadi masyarakat yang terpinggirkan menjadi masyarakat yang memiliki kepercayaan diri untuk meningkatkan martabat dirinya.

Adapun prinsip-prinsip pemberdayaan menurut Soedijanto diantaranya adalah kesukarelaan, otonom, keswadayaan, partisipatif, egaliter, demokrasi, keterbukaan, kebersamaan, akuntabilitas, dan desentralisasi (Mardikanto dan Purwoko Soebiato 2017: 108 - 109). Prinsip-prinsip ini layak untuk dimanifestasikan agar proses pemberdayaan menghasilkan dampak yang positif bagi masyarakat yang diberdayakan. Partisipasi warga sangat dibutuhkan dalam proses pemberdayaan disertai dengan keterbukaan dan kebersamaan antara sesama warga. Kemandirian warga juga dibutuhkan untuk mendukung proses pemberdayaan.

Berkaitan dengan pemberdayaan masyarakat di bidang pariwisata, Sunaryo mengemukakan tiga prinsip dalam strategi perencanaan pembangunan pariwisata yaitu (1) mengikutsertakan anggota masyarakat dalam pengambilan keputusan, (2) adanya kepastian masyarakat lokal menerima manfaat dari kegiatan kepariwisataan, (3) pendidikan kepariwisataan bagi masyarakat lokal (2013: 140). Masyarakat harus dilibatkan dalam pengambilan keputusan karena masyarakat yang mengetahui bidang-bidang apa saja yang signifikan untuk diberdayakan pada kegiatan pariwisata di daerahnya. Masyarakat juga harus menerima manfaat dari kegiatan pariwisata di daerahnya karena mereka hidup di daerah wisata tersebut. Sedangkan untuk memberdayakan masyarakat di bidang pariwisata, masyarakat harus dibekali dengan wawasan dan pengetahuan di bidang pariwisata sehingga masyarakat dapat memberdayakan dirinya selaras dengan kegiatan di bidang pariwisata.

Sunaryo menambahkan bahwa salah satu strategi pembangunan kepariwisataan adalah strategi perencanaan pembangunan kepariwisataan yang bertumpu pada pemberdayaan masyarakat (community based tourism development) (2013: 132). Sunaryo juga menambahkan bahwa salah satu prinsip dalam konsep pengembangan pariwisata berbasis masyarakat (community based tourism development) yaitu pengembangan kepariwisataan harus memberikan nilai sosial, ekonomi yang sebesar-besarnya bagi masyarakat setempat (2013: 229). Dengan demikian, masyarakat di daerah pariwisata dapat berperan serta untuk mengembangkan pariwisata di daerahnya. Masyarakat di daerah wisata tidak menjadi masyarakat yang terpinggirkan saat pariwisata di daerahnya berkembang terlebih saat para investor dapat mengakses dengan mudah dalam menanamkan investasinya di daerah wisata tersebut. Masyarakat di daerah wisata harus menjadi pihak yang diuntungkan sejalan dengan pesatnya perkembangan pariwisata di daerahnya.

Dalam mengelola pariwisata di suatu daerah, peran serta masyarakat sangat penting mulai dari perencanaan sampai pada implementasi suatu kebijakan. Konsep perencanaan 
pengembangan wisata berbasis masyarakat (Community Based Tourism Development) perlu untuk direalisasikan secara nyata. Pengembangan pariwisata berbasis masyarakat dapat memotivasi masyarakat untuk berperan aktif dalam kegiatan pariwisata. Dikatakan oleh Sunaryo bahwa inti tujuan dari pada otonomi daerah di bidang kepariwisataan sebetulnya adalah terciptanya kemandirian lokal khususnya kemandirian masyarakat di destinasi. Sementara untuk mengembangkan kemandirian lokal tadi, upaya pemberdayaan sumber daya manusia terkait serta potensi lingkungan kepariwisataan setempat menjadi sangat penting (2013: 156). Hal ini juga ditegaskan Hausler, CBT pada hakekatnya merupakan salah satu pendekatan dalam pembangunan pariwisata yang menekankan masyarakat lokal, baik yang terlibat langsung dalam industri pariwisata maupun tidak, dalam bentuk pemberian akses pada manajemen dan sistem pembangunan kepariwisataan yang berujung pada pemberdayaan politis melalui kehidupan yang lebih demokratis, termasuk dalam pembagian keuntungan dari kegiatan kepariwisataan secara lebih adil bagi masyarakat lokal (Sunaryo 2013: 139). Nyata bahwa masyarakat lokal yang terlibat langsung dalam industri pariwisata dapat merasakan dampak positifnya. Masyarakat dapat merasakan keadilan atas perolehan keuntungan dari pengembangan pariwisata di daerahnya. Masyarakat sekitar lokasi wisata bukan menjadi pihak yang termarginalkan tetapi mampu berkontribusi positif untuk mengembangkan pariwisata di daerahnya. Murphy memberikan beberapa batasan pengertian tentang CBT (Community Based Tourism Development) yaitu: (1) Wujud tata kelola kepariwisataan memberikan kesempatan kepada masyarakat lokal untuk mengontrol dan terlibat aktif dalam manajemen dan pembangunan kepariwisataan yang ada, (2), Wujud tata kelola kepariwisataan yang dapat memberikan kesempatan pada masyarakat yang tidak terlibat langsung dalam usaha-usaha kepariwisataan juga bisa mendapat keuntungan dari kepariwisataan yang ada, (3) Bentuk kepariwisataan yang menuntut pemberdayaan secara sistematik dan demokratis serta distribusi keuntungan yang adil kepada masyarakat yang kurang beruntung yang ada di destinasi (Sunaryo 2013: 139). Pada intinya masyarakat di daerah wisata harus diberdayakan sehingga masyarakat tersebut dapat terlibat aktif dalam kegiatan pariwisata di wilayahnya. Masyarakat juga mendapat keuntungan dari kegiatan pariwisata di daerahnya.

Pendekatan pengembangan pariwisata melalui CBT sudah selayaknya diterapkan di daerah-daerah sehingga masyarakat merasa ikut memiliki destinasi wisata yang ada didaerahnya dan berpartisipasi untuk mengembangkan destinasi wisata yang ada di daerahnya sehingga menjadi lebih baik dan dapat meningkatkan pendapatan ekonomi masyarakat sekitar daerah wisata. Dengan demikian, masyarakat dapat memperoleh keuntungan dari pengembangan pariwisata di daerahnya. Masyarakat dapat diberdayakan dengan turut berpartisipasi mengelola pariwisata di daerahnya sehingga masyarakat mampu menunjukkan eksistensinya dalam pengelolaan pariwisata di daerahnya. 
Sunaryo mengatakan bahwa dilihat dari sisi pemerintah, peningkatan kapasitas masyarakat secara politis justru akan merupakan cerminan keberhasilan pemerintah dalam proses demokratisasi dan pengembangan good tourism governance itu sendiri. Dapat diharapkan, nantinya pihak pemerintah akan sangat mudah menjalankan program pemberdayaan masyarakat apabila dilakukan di lingkungan komunitas yang telah memiliki moda sosial yang kuat (2013: 224). Dengan demikian, jelas bahwa pemberdayaan masyarakat di daerah wisata sekitar masyarakat tersebut berada mampu membuat masyarakat menjadi semakin berdaya dan hal ini secara tidak langsung menjadi indikator keberhasilan pemerintah dalam memberdayakan masyarakat di sekitar daerah wisata.

Sudah selayaknya masyarakat lokal di daerah wisata diberdayakan sehingga mereka mampu menjadi sumber daya yang dapat meningkatkan potensi wisata yang ada di daerahnya. Masyarakat sekitar lokasi wisata setidaknya paham bagaimana mengembangkan wisata di daerahnya dengan konsep yang tetap menguntungkan masyarakat sekitar. Dengan demikian, keuntungan tidak semata dinikmati pihak swasta yang dalam hal ini lebih berpotensi untuk mendapatkan keuntungan melalui modal yang ditanamkan di daerah wisata. Dengan kata lain, masyarakat perlu diberdayakan untuk mengembangkan wisata di daerahnya. Masyarakat seyogyanya menjadi subyek dalam pengembangan wisata di daerahnya.

Dukungan Pemerintah Kota Yogyakarta terhadap keberadaan kampung-kampung wisata dikuatkan dalam Peraturan Walikota Nomor 115 Tahun 2016 juga melalui konsep CBT (Community Based Tourism). Dengan konsep ini diharapkan kampung-kampung wisata di Kota Yogyakarta, khususnya Kampung Wisata Dewo Bronto dapat lebih memberdayakan masyarakat di kampung tersebut sehingga warga dapat mengembangkan kampung wisata sesuai dengan kapasitas dan keahlian yang dimiliki warga di kampung wisata tersebut. Dampaknya adalah pariwisata di kampung tersebut dapat dikelola lebih baik dan dapat menarik para wisatawan berkunjung ke kampung wisata Dewo Bronto Kota Yogyakarta.

Penelitian sebelumnya dalam bidang pemberdayaan masyarakat dilakukan oleh Jopang, Arifin Utha, dan Eko Harianto dengan judul Pelaksanaan Alokasi Dana Desa (Add) Dalam Bidang Pemberdayaan Masyarakat Di Kabupaten Konawe (2018). Penelitian ini bertujuan untuk menganalisis implementasi anggaran dana desa di bidang pemberdayaan masyarakat di Pulau Wowonii. Hasil menunjukkan bahwa anggaran desa selama kurung waktu 4 (empat) tahun telah memberikan kontribusi pada desa dan masyarakat di Pulau Wowonii County. Pelaksanaan ADD tahun 2017 sangat membantu dalam pemberdayaan masyarakat terutama masyarakat miskin dan kaum perempuan. Pemberdayaan masyarakat yang menjadi unggulan Pemerintah Kabupaten Konawe adalah Program Bedah Rumah dan UEP. 
Ullasan mengenai pemberdayaan masyarakat juga dilakukan oleh Rumsari Hadi Sumarto dan Lukas Dwiantara (2019) dengan judul Pemanfaatan Dana Desa Untuk Peningkatan Taraf Hidup Masyarakat Pedesaan Melalui Pemberdayaan Masyarakat Desa. Adapun tujuan dari penulisan makalah tersebut adalah mendeskripsikan pemberdayaan masyarakat desa melalui Dana Desa sehingga mampu meningkatkan taraf hidup masyarakat pedesaan. Pemanfaatan Dana Desa signifikan untuk mencegah arus urbanisasi. Peluang masyarakat desa untuk meningkatkan taraf hidup terakomodasi melalui pemberdayaan masyarakat dari Dana Desa.

Penelitian dari Anak Agung Istri Andriyani, Edhi Martono, dan Muhamad (2017) dengan judul Pemberdayaan Masyarakat Melalui Pengembangan Desa Wisata Dan Implikasinya Terhadap Ketahanan Sosial Budaya Wilayah (Studi Di Desa Wisata Penglipuran Bali. Penelitian ini bertujuan untuk memahami berlangsungnya proses pemberdayaan masyarakat melalui pengembangan desa wisata di Desa Wisata Penglipuran dan implikasinya terhadap ketahanan sosial budaya wilayah. Pemberdayaan masyarakat melalui pengembangan desa wisata memberikan implikasi terhadap ketahanan sosial budaya wilayah berupa penguatan dan beberapa perubahan pada tata nilai sosial, budaya dan lingkungan.

I Wayan Mudana (2015) dalam penelitian yang berjudul Pemberdayaan Masyarakat di Daerah Tujuan Wisata Desa Pemuteran dalam Rangka Pengembangan Pariwisata Berkelanjutan. Penelitian ini bertujuan untuk mendeskrepsikan tentang bentuk pemberdayaan masyarakat dalam pengembangan pariwisata yang berkelanjutan di Desa Pemuteran. Dapat dikemukakan bahwa bentuk pemberdayaan yang dikembangkan adalah bentuk pemberdayaan masyarakat lokal. Strategi pemberdayaannya dilakukan secara terpadu baik yang bersifat mikro, mezzo, maupun makro.

Dari keempat penelitian sebelumnya, dua penelitian fokus membahas pemberdayaan masyarakat khususnya berkenaan dengan pemanfaatan dana desa yang dapat meningkatkan taraf hidup masyarakat di desa terutama untuk masyarakat miskin dan kaum perempuan. Sedang penelitian lain mengulas tentang pemberdayaan masyarakat dalam pengembangan desa wisata, dan penelitian lainnya mengulas pemberdayaan masyarakat dalam pengembangan desa wisata yang dilakukan secara terpadu baik bersifat mikro, mezzo maupun makro. Perbedaan dengan penelitian ini adalah pemberdayaan masyarakat Kampung Wisata Dewo Bronto dilakukan melalui konsep Community Bases Tourism (CBT) dan lokasi penelitian berada di kota bukan dipedesaan. Permasalahan di kota pada umumnya lebih kompleks dan kondisi sosial ekonomi masyarakat di kampung wisata yang sangat heterogen. Interaksi sosial di antara warga di kota juga berbeda dengan di desa yang pada umumnya memiliki status sosial yang homogen sehingga memudahkan warga berinteraksi antara sesama warga. Dengan demikian, dibutuhkan komitmen yang kuat dari warga kota untuk bersama-sama mengembangkan kampung wisata di wilayahnya. 
Sifat individualis masyarakat kota dapat menjadi kendala dalam kegiatan pemberdayaan di bidang pariwisata.

Berdasarkan latar belakang masalah yang telah dipaparkan, maka rumusan masalah dalam penelitian ini adalah bagaimanakah kegiatan pemberdayaan masyarakat pada pengelolaan pariwisata di Kampung Wisata Dewo Bronto Kota Yogyakarta melalui konsep Community Based Tourism (CBT). Sedang tujuan dari penelitian mengenai pemberdayaan masyarakat dalam Pengelolaan Pariwisata di Kampung Wisata Kota Yogyakarta yaitu untuk mendeskripsikan dan menganalisis kegiatan pemberdayaan masyarakat pada Kampung Wisata Dewo Bronto Kota Yogyakarta melalui konsep Community Based Tourism (CBT).

\section{METODOLOGI}

Penelitian ini menggunakan jenis penelitian kualitatif. Penelitian kualitatif tidak menguji hipotesa, tetapi penelitian ini mendeskripsikan informasi yang didapat secara obyektif (Sugiyono dalam Pasolong 2013: 76). Penelitian kualitatif di Kampung Wisata Dewo Bronto Kota Yogyakarta mendeskrisikan informasi mengenai pemberdayaan masyarakat melalui konsep Community Based Tourism secara obyektif berdasar temuan data di lapangan. Data -data yang didapat di di Kampung Wisata Dewo Bronto baik data primer maupun sekunder, data hasil wawancara, pengamatan dan dokumentasi yang berkaitan dengan pemberdayaan masyarakat pada kegiatan wisata di kampung tersebut dideskripsikan secara obyektif.

Teknik pengumpulan data yang digunakan dalam penelitian ini adalah metode pengamatan atau observasi, wawancara, dan dokumentasi. Observasi dilakukan untuk mengamati secara langsung kegiatan pemberdayaan masyarakat dalam pengelolaan pariwisata pada masyarakat di Kampung Wisata Dewo Bronto Kota Yogyakarta melalui konsep Community Based Tourism. Peneliti mengamati kegiatan warga yang berkaitan dengan kegiatan pariwisata. Pada teknik wawancara, informasi yang digali dari informan adalah kegiatan pemberdayaan masyarakat pada pengelolaan pariwisata di kampung Wisata Dewo Bronto Kota Yogyakarta melalui konsep Community Based Tourism. Informan dalam hal ini adalah pengelola Kampung Wisata Dewo Bronto, masyarakat Kampung Wisata Dewo Bronto termasuk pelaku pariwisata yang bergerak di bidang produksi batik, kuliner, homestay, dan transportasi. Pada teknik dokumentasi, peneliti melakukan pengumpulan data melalui pencarian berbagai dokumen baik peraturan-peraturan, gambar, catatan, sejarah dan laporan yang berkenaan dengan kegiatan pemberdayaan masyarakat dalam pengelolaan pariwisata di Kampung Wisata Kota Yogyakarta melalui konsep Community Based Tourism. Dokumentasi juga didapatkan dari hasil rekaman gambar yang dilakukan peneliti saat terjun ke lokasi penelitian di Kampung Wisata Dewo Bronto Kota Yogyakarta.

Instrumen penelitian menggunakan guide interview, pengamatan, dan dokumentasi. Analisis 
data dalam metode kualitatif pada dasarnya bermula dari pengambilan data di tempat penelitian yaitu di Kampung Wisata Dewo Bronto Kota Yogyakarta. Data yang telah diperoleh saat peneliti berada di lokasi penelitian kemudian dikumpulkan. Data yang terkumpul direduksi kemudian diinterpretasi. Hasil dari interpretasi akan menghasilkan data yang sesuai dengan pokok-pokok yang sejalan dengan permasalahan dan tujuan penelitian. Langkah selanjutnya adalah peneliti membuat kesimpulan setelah data diinterpretasi. Kemudian peneliti memberi rekomendasi atas penelitian yang dilakukan.

\section{HASIL DAN PEMBAHASAN}

Pariwisata sedang menjadi ikon dalam kehidupan bernegara di mana pun negara tersebut berada karena tingginya animo masyarakat untuk mengunjungi suatu destinasi wisata. Kota Yogyakarta juga menjadi salah satu tujuan wisata dari para wisatawan yang berkunjung ke daerah Istimewa Yogyakarta baik wisatawan domestik dan wisatawan mancanegara. Beragam destinasi wisata berada di Kota Yogyakarta. Destinasi wisata yang sangat terkenal di Indonesia bahkan penjuru dunia adalah Kawasan Malioboro. Kawasan Malioboro identik dengan ikon wisata di Kota Yogyakarta. Namun demikian, sebenarnya banyak destinasi wisata lain yang ada di Kota Yogyakarta. Ciri khas destinasi wisata yang ada di Kota Yogyakarta mayoritas merupakan berupa pagelaran atraksi seni dan budaya serta situs-situs bersejarah seperti Taman Sari, Situs Warungboto dan situs-situs yang ada di Kota Gede. Salah satu destinasi wisata di Kota Yogyakarta adalah kampung-kampung wisata. Kampung wisata di Kota Yogyakarta memang belum menjadi tujuan wisata utama bagi para wisatawan yang berkunjung ke Yogyakarta. Sementara itu, kampung wisata sebenarnya memiliki beragam atraksi seni dan budaya yang unik dan khas yang membedakan antara kampung wisata yang satu dengan kampung wisata lainnya. Oleh karena itu, Pemerintah Kota Yogyakarta perlu mendukung penuh pengembangan kampung-kampung wisata agar lebih dikenal para wisatawan. Dukungan Pemerintah Kota Yogyakarta terhadap keberadaan kampung-kampung wisata yang dikuatkan dalam Peraturan Walikota Nomor 115 Tahun 2016 memaparkan pentingnya pemberdayaan masyarakat di kampung-kampung wisata melalui konsep CBT (Community Based Tourism). Masyarakat di kampung-kampung wisata diharapkan dapat diberdayakan melalui CBT (Community Bassed Tourism). Konsep Community Based Tourism mengedepankan masyarakat sebagai penggerak utama penggiat pariwisata di kampungnya. Masyarakat diharapkan paham bagaimana mengelola kegiatan-kegiatan yang berkaitan dengan pariwisata. Oleh karena itu, kampung-kampung wisata yang ada di Kota Yogyakarta khususnya Kampung Wisata Dewo Bronto seyogyanya dapat menerapkan Community Based Tourism sehingga masyarakat dapat benar-benar diberdayakan pada destinasi yang lekat dengan kehidupan masyarakat di kampung tersebut. 
Kampung Wisata Dewo Bronto merupakan salah satu kampung wisata yang ada di Kota Yogyakarta. Kampung wisata ini berada di pinggiran Kali Code dan kampung wisata ini harus selalu siap mengantisipasi banjir akibat luapan Kali Code di saat musim hujan sehingga tidak menghambat wisatawan yang akan berkunjung ke Kampung Wisata Dewo Bronto dan juga tidak menghambat warga dalam beraktivitas terutama aktivitas yang berkenaan dengan kegiatan pariwisata. Oleh karena itu, Pemerintah Kota Yogyakarta meminta kampung wisata Dewo Bronto menjaga kebersihan kali Code. Dengan kondisi kali Code yang bersih, maka keberadaan kampung wisata Dewo Bronto akan terhindar darii banjir saat musim hujan dan tidak menghambat para wisatawan yang ingin berkunjung ke Kampung Wisata Dewo Bronto karena terkendala banjir.

Selain fokus pada pemeliharaan kebersihan Kali Code, Kampung Wisata Dewo Bronto memiliki beragam kegiatan yang berhubungan dengan atraksi seni dan budaya seperti upacara adat, jemparingan dan bregodo. Tradisi seni dan budaya di Kampung Wisata Dewo Bronto ini dilestarikan dengan menggelar atraksi seni dan budaya di waktu-waktu tertentu. Selain atraksi seni dan budaya, di Kampung Wisata Dewo Bronto juga terdapat wisata kuliner seperti wedang bajigur dan gudeg serta industri wisata batik pewarna alam. Paket wisata dengan rangkaian atraksi seni dan budaya juga wisata kuliner dan batik akan digelar berdasar permintaan dari para wisatawan dalam jumlah besar yang berkunjung ke Kampung Wisata Dewo Bronto Kota Yogyakarta. Bila wisatawan dalam jumlah kecil, wisatawan dapat mengunjungi Kampung Wisata dan dapat meminta pengelola Kampung Wisata memandu wisatawan saat berkunjung ke Kampung Wisata Dewo Bronto.

Lurah Brontokusuman menyampaikan juga mengenai wisata di Kampung Wisata Dewo Bronto:

Dewo Bronto identik dengan mengusung wisata kali bersih karena posisinya berada di pinggir Kali Code. Selain itu Kampung Wisata Dewo Bronto juga terkenal dengan ikon wisata kuliner gudeg Eco, wedang bajigur. Sedangkan fasilitas pendukung di bidang pariwisata terdapat fasilitas homestay dan transportasi city tour. Kampung Wisata Dewo Bronto juga dekat dengan Prawirotaman yang terkenal dengan kampung turis (wawancara dengan Lurah Brontokusuman pak Maryanto 26 Agustus 2019).

Selain mempersiapkan atraksi seni dan budaya, wisata kuliner dan wisata batik dan wisata lainnya, Kampung Wisata Dewo Bronto sebagai salah satu destinasi wisata di Kota Yogyakarta juga mempersiapkan pendukung wisata lainnya seperti homestay dan transportasi. Kampung wisata ini dekat dengan Prawirotaman yang lebih dikenal sebagai kampung turis sehingga banyak turis yang singgah ke Kampung Wisata Dewo Bronto.

Produk batik yang terkenal di Kampung Wisata Dewo Bronto adalah batik pewarna alam. Batik ini berbeda dengan produk batik lainnya yang memakai pewarna buatan dengan bahan kimia. Pembuatan batik dengan pewarna alam sangat mendukung dalam pelestarian alam sehingga tidak mencemari lingkungan dan Kali Code yang melewati 
Open Access at: http://ojs.uho.ac.id/index.php/PUBLICUHO/index

Kampung Wisata Dewo Bronto. Bidang usaha batik pewarna alam yang diproduk oleh warga di Kampung Wisata Dewo Bronto pada awalnya merupakan rintisan UMKN usaha batik yang diselenggarakan Kelurahan Brontokusuman Yogyakarta.

Seiring dengan gencarnya program promosi wisata dan UMKM, Kelurahan membentuk usaha UMKM dengan menghidupkan kembali usaha batik. Para perajin batik di kawasan ini lantas membentuk Paguyuban. Namanya Paguyuban Batik "Canthing Makaryo". Selain membeli batik dengan pewarna alam yang ramah lingkungan untuk oleh-oleh, wisatawan bisa juga praktik membatik di Kampung Wisata Dewa Bronto. https://batampos.co.id/2017/04/12/kisah-inspiratif-dari-kampung-wisata-dewa-bronto (diakses 1 November 2019).

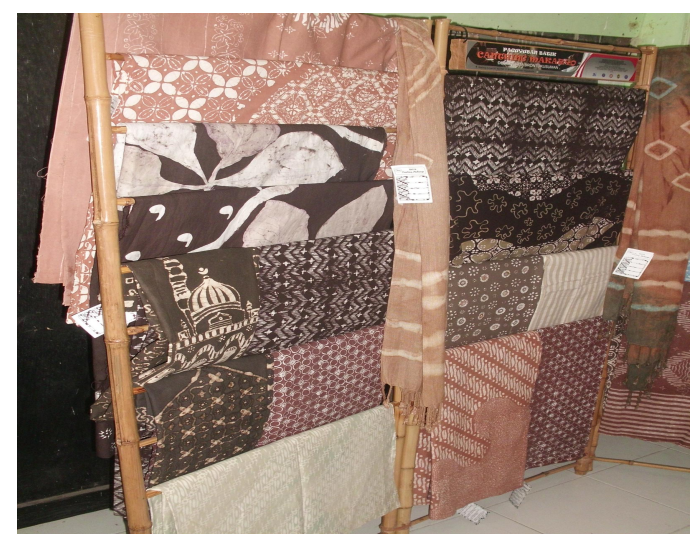

Gambar 1. Batik Pewarna Alam

Sumber: Dokumentasi Penelitian, 2019

Industri wisata yang memproduk batik pewarna alam di Kampung Wisata Dewo Bronto sudah menjadi bidang usaha bagi para ibu-ibu di Kampung Wisata Dewo Bronto melalui Paguyuban Canthing Makaryo. Produksi batik pewarna alam ini juga menjadi sarana pelatihan bagi para warga yang tertarik untuk belajar memproduk batik pewarna alam sehingga warga memiliki ketrampilan memproduk batik pewarna alam tersebut. Dengan adanya ketrampilan membuat batik dengan pewarna alam, maka warga dapat memproduk batik yang dapat dipasarkan secara bersama-sama melalui Paguyuban Canthing Makaryo. Dengan demikian, warga dapat membuat batik pewarna alam tersebut di rumah masing-masing dan kemudian diserahkan ke Paguyunan Canthing Makaryo. Dengan adanya produksi batik yang dilakukan di rumah-rumah warga, maka secara tidak langsung warga diberdayakan melalui produksi batik pewarna alam. Selain warga memiliki kegiatan membatik, warga juga mendapatkan penghasilan dari produksi batik pewarna alam.

Adapun kegiatan pelatihan membatik ini juga disampaikan oleh Ketua Paguyuban Canthing Makaryo Kampung Wisata Dewo Bronto Bapak Khusnan. 
"Setiap Rabu diadakan kegiatan latihan membatik pewarna alam yang diselenggarakan oleh Paguyuban Canting Makaryo. Karena lokasi Kampung Wisata Dewo Bronto dekat dengan Prawirotaman yang dikenal sebagai kampung turis, maka para wisatawan dari luar negeri juga sering mampir ke Kampung Wisata Dewo Bronto dan membeli batik pewarna alam Dewo Bronto" (wawancara dengan Ketua Paguyuban Canthing Makaryo pak Khusnan 26 Agustus 2019).

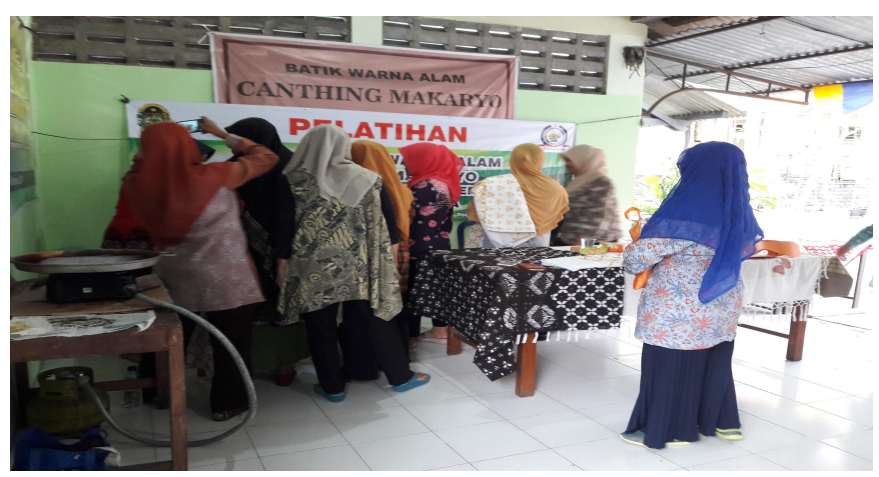

Gambar2. Kegiatan Kelompok Canthing Makaryo Sumber: Dokumentasi Penelitian, 26 Agutus 2019

Paguyuban batik Canthing Makaryo merupakan kegiatan yang memberdayakan masyarakat dalam pembuatan produk batik yang menggunakan pewarna alam. Melalui usaha pembuatan produk batik pewarna alam ini, masyarakat terutama para ibu-ibu yang semula tidak memiliki kegiatan usaha, maka saat ini dapat mengisi waktu luang dengan memproduk batik pewarna secara bersama-sama yang tergabung dalam Paguyuban Canthing Makaryo. Kegiatan ini tentu saja menghasilkan keuntungan bagi para ibu-ibu yang semula tidak memiliki penghasilan menjadi masyarakat yang dapat menghasilkan pendapatan bagi dirinya sendiri dan berdampak pada meningkatnya taraf hidup masyarakat di Kampung Wisata Dewo Bronto.

Selain pelatihan membatik dengan pewarna alam di Kampung Wisata Dewi Bronto, pelatihan lain yang mendukung pariwisata juga diikuti oleh warga Kampung Wisata Dewo Bronto. Pelatihan diselenggarakan oleh Dinas Pariwisata Kota Yogyakarta. Hal ini disampaikan oleh Ketua Kampung Wisata Dewo Bronto Bapak Marsudi.

\begin{abstract}
"Selain pelatihan yang diselenggarakan di Kampung Wisata seperti pelatihan membatik dengan pewarna alam, pelatihan lain juga diikuti oleh warga Kampung Wisata Dewo Bronto. Pelatihan yang diikuti oleh warga dan pengelola Kampung Wisata Dewo Bronto Kota Yogyakarta diantaranya adalah pelatihan pengelola homestay, pelatihan pengelola kuliner, pelatihan guide, pelatihan manajemen bagi pengelola kampung wisata dan pelatihan lainnya. Pelatihan ini diselenggarakan oleh Dinas Pariwisata Kota Yogyakarta" (wawancara dengan Ketua Kampung Wisata Dewo Bronto pak Marsudi 26 Agustus 2019)
\end{abstract}

Dengan adanya pelatihan yang diikuti warga Kampung Wisata Dewo Bronto, warga dapat memberdayakan dirinya dengan menekuni bidang-bidang usaha yang sesuai dengan kemampuan warga. Pelatihan guide sangat diperlukan di mana Kampung Wisata Dewo 
Open Access at: http://ojs.uho.ac.id/index.php/PUBLICUHO/index

Bronto ini sering dikunjungi turis dari Prawirotaman. Pelatihan bidang usaha kuliner juga sangat mendukung bagi warga yang sudah berwirausaha di bidang kuliner sehingga warga semakin profesional dalam mengelola usaha kuliner. Pelatihan bidang usaha kuliner juga bermanfaat bagi warga yang ingin berusaha di bidang kuliner sesuai dengan kemampuan yang dimiliki. Pelatihan pengelola homestay sangat diperlukan bagi warga yang memiliki usaha di bidang homestay sehingga homestay yang dimiliki dapat memenuhi kriteria yang dipersyaratkan. Homestay saat ini menjadi pilihan bagi para wisatawan karena model penginapan yang menyerupai suasana rumah tangga dan harga terjangkau serta suasana penginapan yang berbaur dengan rumah-rumah warga. Mengingat besarnya animo wisatawan yang memilih homestay sebagai tempat tinggal sementara di daerah wisata, maka pelatihan pengelola homestay ini sangat diperlukan agar pengelola homestay lebih profesional dalam mengelola homestay yang dimiliki. Dengan menekuni bidang usaha yang sesuai dengan kemampuan warga, maka usaha tersebut dapat menjadi sarana warga untuk memperoleh pendapatan.

Pelatihan manajemen bagi pengelola kampung wisata juga bermanfaat bagi para pengelola untuk lebih kreatif dan trampil dalam mengelola destinasi wisata di Kampung Wisata Dewo Bronto. Pelatihan manajemen bagi pengelola kampung wisata juga bermanfaat dalam mengelola para warganya sehingga warga memiliki kepedulian untuk bersama-sama menjaga kampung wisata agar tetap bersih dan menarik sehingga wisatawan tertarik untuk berkunjung ke Kampung Wisata Dewo Bronto Kota Yogyakarta.

Selain pelatihan yang diikuti warga sehingga warga diberdayakan dengan bekal wawasan yang didapatkan, maka untuk lebih memperkenalkan hasil dari bidang usaha yang diproduk warga Kampung Wisata Dewo Bronto, Kampung Wisata Dewi Bronto mengikuti Festival Kampung Wisata yang diselenggarakan Dinas Pariwisata Kota Yogyakarta. Promosi mengenai Keberadaan Kampung Wisata Dewo Bronto yang memperkenalkan produk-produk yang dihasilkan dan memperkenalkan atraksi seni dan budaya yang ada di Kampung Wisata Dewo Bronto dilakukan dengan mengikuti Festival Kampung Wisata Kota Yogyakarta yang digelar pada tanggl 7 - 8 September 2019 di XT Square Yogyakarta.

Pada hari Sabtu, 7 September 2019 pada Festival Kampung Wisata yang diadakan oleh Dinas Pariwisata Kota Yogyakarta, Kampung Wisata Dewa Bronto Kelurahan menggelar produk oleh-oleh (Batik Canthing makaryo), Wedang khas bajigur Dewa Bronto dan Memperkenalkan kampung wisata Dewa Bronto. https://www.atmago.com/post/kampungwisata-dewa-bronto-di-xt-square 7708a2f9-cdfa-4771-bdla-9c46c91387d5 (diakses I November 2019). 


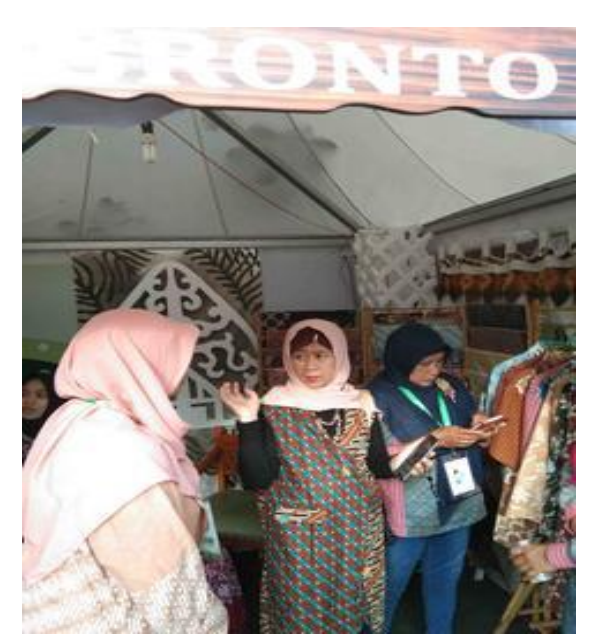

Gambar 3. Gerai Kampung Wisata Dewo Bronto pada Festival Kampung Wisata di XT Square Yogyakarta.

Sumber: https://www.atmago.com/post/kampung-wisata-dewa-bronto-di-xt-square 7708a2f9cdfa-4771-bd1a-9c46c91387d5

Festival kampung wisata ini dapat menjadi sarana untuk lebih memperkenalkan Kampung Wisata Dewo Bronto kepada para wisatawan. Pagelaran seni dan budaya ditampilkan pada acara Festival tersebut. Stand kampung wisata juga diisi dengan produk dari bidang usaha yang dilakukan warga seperti batik pewarna alam, kuliner dan informasi homestay serta informasi lain sekitar Kampung Wisata Dewo Bronto Kota Yogyakarta. Festival yang diselenggarakan Dinas Pariwisata Kota Yogyakarta sangat bermanfaat bagi kampung wisata karena dapat memfasilitasi kampung wisata untuk memperkenalkan kampung wisatanya beserta kegiatan wisata yang ada di kampung wisata tersebut.

Selain mengikuti Festival Kampung Wisata Kota Yogyakarta, promosi Kampung Wisata Dewo Bronto juga dilakukan melalui media sosial seperti facebook dan instagram. Hal ini disampaikann oleh Ketua Kampung Wisata Dewo Bronto.

"Promosi mengenai keberadaan Kampung Wisata Dewo Bronto selain dilakukan dengan mengikuti Festival Kampung Wisata yang diselenggarakan Pemerintah Kota Yogyakarta melalui Dinas Pariwisata Kota Yogyakarta, promosi juga dilakukan dengan berbagai sarana media seperti media sosial yaitu facebook dan instagram. Setiap kegiatan yang digelar seperti upacara adat dan atraksi lainnya diunggah di media sosial tersebut sehingga dapat diakses masyarakat. Promosi juga dilakukan melalui media massa". (wawancara dengan Bapak Marsudi Ketua Kampung Wisata Dewo Bronto Kota Yogyakarta 26 Agustus 2019)

Usaha memperkenalkan Kampung Wisata melalui berbagai media memang harus dilakukan agar Kampung Wisata Dewo Bronto semakin dikenal masyarakat. Usaha memperkenalkan Kampung Wisata Dewo Bronto salah satunya dengan menyelenggarakan Upacara Adat Merti Tumpeng Robyong disambut baik oleh wisatawan asing.

Serombongan wisatawan asing tampak asyik menikmati tumpeng dalam Upacara Adat Merti Tumpeng Robyong Kampung Wisata Dewa Bronto. Wisatawan dari Kanada dan Belanda itu duduk mengitari tumpeng dan mengambil nasi serta lauknya. "So delicious. I like it (enak sekali, saya suka)," ujar Sofie asal Montreal saat ditanya mengenai makanan yang dicicipinya seperti dikutip dalam rilis Kemenpar, Minggu 
(23/4/2017). Dia merasa senang bisa mengikuti prosesi Merti Tumpeng Robyong yang menyajikan sejumlah atraksi seni. https://www.cnnindonesia.com/gayahidup/20170423143803-307-209582/wisatawan-asing-pun-ikut-asyik-nikmati-tumpeng (diakses 1 November 2019)

Penyelenggaraan Upacara Adat Merti Tumpeng Robyong Kampung Wisata Dewa Bronto merupakan salah atraksi budaya yang dilakukan warga. Bagi wisatawan domestik yang berasal dari luar Kota Yogyakarta dan wisatawan dari mancanegara, upacara adat ini sangat menarik karena selain wisatawan dapat melihat prosesi upacara adat, wisatawan juga dapat menikmati tumpeng dalam atraksi budaya tersebut.

Menurut Ketua Kampung Wisata Dewo Bronto ada beberapa atraksi seni dan budaya yang sering digelar oleh warga Kampung Wisata Dewo Bronto.

"Ketua Kampung Wisata Dewo Bronto mengatakan bahwa selain atraksi budaya Upacara Adat Merti Tumpeng Robyong yang digelar untuk para wisatawan, Kampung Wisata Dewo Bronto juga menggelar atraksi seni dan budaya yang merupakan permintaan dari wisatawan dan atraksi budaya seperti bregodo, jemparingan dan kegiatan budaya lainnya". (wawancara dengan Ketua Kampung Wisata Dewo Bronto Bapak Marsudi 26 Agustus 2019).

Kampung Wisata Dewo Bronto sebagai salah satu destinasi wisata yang ada di Kota Yogyakarta identik dengan mengusung budaya dalam setiap atraksi yang digelar. Pelestarian budaya ini sangat diperlukan agar dapat diteruskan kepada generasi berikutnya yang tinggal di Kampung Wisata Dewo Bronto Kota Yogyakarta.

Untuk mendukung sarana transportasi wisatawan, salah satu pelaku pariwisata di Kampung Wisata Dewo Bronto memiliki usaha rental mobil.

\begin{abstract}
"Untuk mendukung para wisatawan yang akan berwisata, salah satu pelaku pariwisata memiliki usaha jasa transportasi untuk memenuhi permintaan wisatawan yang membutuhkan sarana transportasi walaupun dalam skala yang tidak begitu besar. Usaha jasa transportasi ini dibutuhkan wisatawan terutama wisatawan yang menginap di sekitar Kampung Wisata Dewo Bronto sehingga wisatawan dapat melakukan perjalanan wisata di Kota Yogyakarta ataupun wisatawan lain yang ingin melakukan perjalanan wisata ke luar Kota Yogyakarta". (wawancara dengan pak Indarto 30 November 2019).
\end{abstract}

Di bidang kuliner, warga di Kampung Wisata Dewo Bronto giat mempromosikan wedang bajigur yang merupakan salah satu minuman khas di Yogyakarta.

"Untuk usaha kuliner, warga menyajikan wedang bajigur yang dapat dinikmati wisatawan pada malam hari. Minuman ini dibuat khusus sehingga memiliki cita rasa yang khas dari Kampung Wisata Dewo Bronto. Wedang bajigur ini memang terkenal di Yogyakarta dengan ciri khas minuman tradisional yang perlu dilestarikan" (wawancara dengan Bapak Marsudi Ketua Kampung Wisata Dewo Bronto 26 Agustus 2019)

Berbagai kegiatan yang dilakukan oleh para warga di Kampung Wisata Dewo Bronto Kota Yogyakarta pada dasarnya merupakan bentuk pemberdayaan masyarakat di bidang 
pariwisata dengan berbagai cara dan berbagai bidang yang dikelola baik pada pagelaran seni dan budaya, kuliner, produksi batik, dan transportasi. Pemberdayaan masyarakat di Kampung Wisata dewo Bronto pada dasarnya sudah berjalan baik dan benar-benar melibatkan warga untuk berusaha atau terlibat dalam kegiatan yang dapat mendukung pariwisata di kampung tersebut baik dalam bidang usaha maupun pagelaran atraksi seni dan budaya. Namun demikian, usaha secara berkesinambungan perlu dilakukan agar produk yang dihasilkan menjadi lebih berkualitas, sedangkan atraksi seni dan budaya yang digelar untuk para wisatawan dapat menarik para wisatawan untuk berkunjung ke Kampung Wisata Dewo Bronto

\section{KESIMPULAN}

Destinasi wisata Kampung Wisata Dewo Bronto belum mampu menarik para wisatawan untuk berkunjung ke kampung-kampung wisata di Kota Yogyakarta. Salah satu kampung wisata di Kota Yogyakarta yaitu Kampung Wisata Dewo Bronto juga belum sepenuhnya mampu menarik para wisatawan secara rutin untuk berkunjung ke kampung wisata tersebut. Beberapa wisatawan mancanegara memang tertarik berkunjung ke Kampung Wisata Dewo Bronto. Sedang prosentase wisatawan domestik yang berkunjung ke kampung wisata ini dapat dikatakan belum tinggi. Sementara itu warga di Kampung Wisata Dewo Bronto banyak melakukan aktivitas yang mendukung dalam pengembangan pariwisata di kampung tersebut. Aktivitas yang dilakukan merupakan bentuk pemberdayaan masyarakat di daerah wisata yang lebih dikenal dengan Community Based Tourism.

\section{SARAN}

Ke depan perlu dilakukan penelitian pada warga usia berkategori milenial yang sangat familiar dengan dunia digital sehingga Kampung Wisata Dewo Bronto khususnya dan kampung wisata secara umum dapat lebih dikenal para wisatawan melalui dunia digital baik melalui media sosial dan media digital lainnya.

\section{DAFTAR PUSTAKA}

Andriyani, Anak Agung Istri, Edhi Martono, dan Muhamad. 2017. Pemberdayaan Masyarakat Melalui Pengembangan Desa Wisata Dan Implikasinya Terhadap Ketahanan Sosial Budaya Wilayah (Studi Di Desa Wisata Penglipuran Bali. JURNAL KETAHANAN NASIONAL. ISSN: 08539340 (Print), ISSN: 2527-9688 (Online) http://jurnal.ugm.ac.id/JKN . Volume 23 No. 1, 27 April 2017. Hal 1-16

Atmago.com. Kampung Wisata Dewa Bronto di XT Square. https://www.atmago.com/post/kampung-wisata-dewa-bronto-di-xt-square_7708a2f9cdfa-4771-bdla-9c46c91387d5 (diakses 1 November 2019)
Balipost.com.
2017.
Ajak
Wisatawan
Makan
Bersama.

http://www.balipost.com/news/2017/04/15/5547/Ajak-Wisatawan-Makan-Bersama

(diakses 1 November 2019) 
Volume 2 Number 4 (November-January), (2019) pp.111 -127

Open Access at: http://ojs.uho.ac.id/index.php/PUBLICUHO/index

Batampos.co.id. 2017. Kisah Inspiratif dari Kampung Wisata Dewa Bronto. https://batampos.co.id/2017/04/12/kisah-inspiratif-dari-kampung-wisata-dewa-bronto (diakses 1 November 2019)

cnnindonesia.com. 2017. Wisatawan Asing pun Ikut Asyik Nikmati Tumpeng. https://www.cnnindonesia.com/gaya-hidup/20170423143803-307-209582/wisatawanasing-pun-ikut-asyik-nikmati-tumpeng (diakses 1 November 2019)

Damanik Phil Janianton. 2013. Pariwisata Indonesia Antara Pelvang dan Tantangan. Yogyakarta: Pustaka Pelajar

Jopang, Arifin Utha, dan Eko Harianto. 2018. Pelaksanaan Alokasi Dana Desa (Add) Dalam Bidang Pemberdayaan Masyarakat Di Kabupaten Konawe, PUBLICUHO Faculty of Social and Political Sciences Halu Oleo University, Kendari, Southeast Sulawesi, Indonesia. ISSN: 2460-058X | e-ISSN: 2621-1351. Open Access at: http://ojs.uho.ac.id/index.php/PUBLICUHO, hal $18-36$

Laporan Kinerja Dinas Pariwisata Kota Yogyakarta 2018

Mardikanto, Totok dan H. Purwoko Soebianto. 2017. Pemberdayaan Masyarakat dalam Perspektif Kebijakan Publik. Bandung: Alfabeta

Mudana, I Wayan. 2015. dalam penelitian yang berjudul Pemberdayaan Masyarakat di Daerah Tujuan Wisata Desa Pemuteran dalam Rangka Pengembangan Pariwisata Berkelanjutan. Jurnal IImu Sosial dan Humaniora. ISSN: 2303-2898 Vol. 4, No. 2, Oktober 2015. hal 598- 608

Peraturan Walikota Nomor 115 Tahun 2016

Pitana, I Gde dan I Ketut Surya Diarta. 2009. Pengantar Ilmu Pariwisata. Yogyakarta: Andi Offset

Sedarmayanti. 2014. Membangun dan Mengembangkan Kebudayaan dan Industri Pariwisata (Bunga Rampai Tulisan Pariwisata). Bandung: Refika Aditama

Soetomo. 2013. Pemberdayaan Masyarakat, Mungkinkah Muncul Anti Tesisnya? Yogyakarta: Pustaka Pelajar

Sumarto, Rumsari Hadi, dan Lukas Dwiantara. 2019. Pemanfaatan Dana Desa Untuk Peningkatan Taraf Hidup Masyarakat Pedesaan Melalui Pemberdayaan Masyarakat Desa. Journal PUBLICUHO Facultyof Social and Political Sciences Halu Oleo University, Kendari, Southeast Sulawesi, Indonesia. ISSN: 2621-1351(electronic), 2685-0729 (print) Open Access at: http://ojs.uho.ac.id/index.php/PUBLICUHO, Vol.2 No.2. July 2019. pp.65-74

Sunaryo, Bambang. 2013. Kebijakan Pembangunan Destinasi Pariwisata. Yogyakarta: Gava Media

Usman, Sunyoto. 2008. Pembangunan dan Pemberdayaan Masyarakat. Yogyakarta, Pustaka Pelajar

Utama, I Gusti Bagus Rai dan Ni Made Eka Mahadewi. 2012. Metodologi Penelitian Pariwisata dan Perhotelan. Yogyakarta: Penerbit Andi

Yoeti, Oka A. 2008. Pengantar Ilmu Pariwisata. Bandung: Angkasa 